\title{
The Concept and the Tragedy of Culture in Georg Simmel and the constitution of Martin Heidegger's Being-in-the-world
}

\author{
Rafael Teixeira Santos (IC)
}

\begin{abstract}
Following Georg Simmel's essay The concept and the tragedy of culture, this research seeks to establish epistemological openings by criticizing it with a conception of human existence found in Martin Heidegger's Being and Time, mapping the possibilities of man and its culture, tragedy being one of them.
\end{abstract}

Key words: Culture, Phenomenology, Modernity

\section{Introduction}

Georg Simmel's essay The Concept and Tragedy of Culture $(1911)^{2}$ is the culmination of his earlier essays and thoughts about the theme of culture. There, he proposes a philosophical grounding for a definition of culture and goes on to analyze its direction in modern society.

The result is the acknowledgement of a tragedy in this specific way on which the culture unfolds. This tragedy relates, however, first to the way culture is, its very concept. The tragic unfolding, following the definition of tragedy, must not be understood as a mere destruction but as an intrinsic destruction given the very way culture is, and then made possible by the conditions found in modernity.

Martin Heidegger, a reported reader of Simmel's work, sought to lay a path to questioning the meaning of Being in his treatise Being and Time (1927) ${ }^{\prime}$. For that, he went to analyze one being that has a special connection with Being: man - called by its specific mode of being: Dasein, or being-there - which always calls for a world.

I sought to investigate how Heidegger's ontology of being-there can clarify Simmel's engaging with culture, from a reworking of his dialectical philosophical framework to the critical questioning of his diagnostic: what does the understanding of man as being-there can open to the direction of culture as tragedy, in itself and in modernity?

\section{Results and Discussion}

On defining culture, Simmel uses two different ways. On the one hand, he calls culture the unstable - tragic - synthesis between the factual objective product, that is given and still, and the flowing life of the subject. This leads the research to one of its main dilemmas: how to overcome Simmel's dialectic treatment of culture given that the very notion of Heidegger's being-in-the-world eschews a subject that is beyond the world?
That was only possible through the understanding that this dialectic is a mode of the more fundamental existential hermeneutic proposed by Heidegger with being-in-the-world.

The second way Simmel defines culture is as a path from the soul to itself ${ }^{2}$. This relates to what Heidegger calls man's ability to establish projects to himself and also to be projected into existence. This projection is then founding of temporality, as man finds himself thrown into (being) in the world.

\section{Conclusions}

The conclusion follows a twofold consideration. On Being and Time, Division I, culture opens with the consideration of its role on negotiating our everyday who towards others, the way we are cultivated by shared practices. Culture appears, then, as a mean to - within this natural sharedness - turn to be ourselves and be capable of autonomous thinking.

On Division II, temporality is used to reinterpret Division l's structures, and so follows the opening of culture. With culture being a path from the soul to itself, it is a project of man's. But man is given to lay them. The tragedy of culture relies in our flowness, but at the same time it can only be perceived against this mode of temporality.

\section{Acknowledgement}

This work has been made possible by CNPq's sponsorship. I would also like to thank the following persons: Michel N. Netto, for his advising and assisting during the whole research; Gustavo S. Giovannetti, for our many enlightening conversations about Heidegger's thought; Henrique B. Pasti, for introducing me to Simmel's problematic of culture and for his work on it being the starting point of this one.

HEIDEGGER, M. Ser e Tempo. Trad. Fausto Castilho. Campinas/Petrópolis: Editora da Unicamp/Vozes, 2012.

SIMMEL, G. O conceito e a tragédia da cultura. In: Simmel e a Modernidade. Ed. Jessé Souza e Berthold Öelze. Brasília: Universidade de Brasília, 1998, p. 79-108. 